\title{
Orman ve mera alanlarında oluşan toprakların sınıflandırılması: Kabadüz/Ordu*
}

\author{
Soner ŞENYURT ${ }^{\circledR} 1$, Ferhat TÜRKMEN ${ }^{(D)} 1$
}

10rdu Üniversitesi Ziraat Fakültesi Torak Bilimi ve Bitki Besleme Bölümü, Ordu

\begin{abstract}
*Bu çalışma Ordu Üniversitesi Fen bilimleri Enstitüsü Toprak Bilimi ve Bitki Besleme Anabilim Dalı'nda kabul edilen yüksek lisans tezinden hazırlanmıștır.
\end{abstract}

Alınıș tarihi: 8 Ekim 2020, Kabul tarihi: 3 Aralık 2020

Sorumlu yazar: Ferhat TÜRKMEN, e-posta: ferhat_turkmen@hotmail.com

Öz

$\mathrm{Bu}$ araștırma Ordu ili Kabadüz İlçesi Turnalık Beldesinde orman ve mer'a arazilerinde yapılmıștır. Arazide 10 profil açılmış, morfolojik özellikler belirlenmiş ve bunlardan horizon esasına göre 50 adet bozulmuş toprak örneği alınmıștır. Daha sonra yapılan arazi, büro ve laboratuvar çalışmaları sonucunda toprakların taksonomik sınıflandırması yapılmış ve Entisol, Alfisol ve Mollisol olmak üzere 3 ordo belirlenmiş̦tir. Ayrıca toprakların sorunları da belirtilerek, çözüm önerileri getirilmiştir.

Anahtar Kelimeler: Arazi, sınıflandırma, orman, mer'a, Mollisol.

\section{Classification of soils formed in forest and pasture areas: Kabadüz/Ordu}

\begin{abstract}
This research was conducted in the forest and pasture lands in Turnalık Town of Kabadüz District of Ordu Province. Ten soil profiles were opened and described morphological properties and then based on horizon 50 disturbed soil samples were taken. Following field and office studies and laboratory analysis, soil taxonomic classification was done and 3 orders were determined as of Entisol, Alfisol and Mollisol. Also soil problems and recommendation toward these problems were presented.
\end{abstract}

Key words: Land, classification, forest, grassland, Mollisol.

\section{Giriş}

Yeryüzü şekillerindeki orantısızlık ve doğal engebelerin fazla olması Orta ve Doğu Karadeniz Bölgesi topraklarının çok daha az çalışılmasına neden olmuştur. $\mathrm{Bu}$ çalışmayla hedeflenen toprakların fiziksel ve kimyasal özelliklerinin tespit edilmesi, sinıflandırılmaya sokulması, gelecekte yapılacak çalışmalara yol gösterecek aktüel verilerin elde edilmesidir.

Sinıflandırma, yeryüzünde bulunan nesnelerin insanlar tarafindan belirli bir sıralama yapılarak değişik kümeler biçiminde gösterme şeklidir. Sınıflandırma yapmada asıl amaç elde edilen bilgileri düzenli hale getirmek, nesnelerin ana özelliklerini göz önüne sermek ve bunların karşılaştırılmasını daha kolay hale getirmektir. Aynı durum toprakların tanımlanması ve sınıflandırılması için de geçerlidir. Toprak sınıflandırılmasında toprağın fiziksel ve kimyasal özellikleri, horizon miktarı ve türü de göz önünde bulundurulur (Smith, 1983).

Ülkemizde toprakların sinıflandırılması amacıyla yapılan ilk çalışmalardan olan Kerim Ömer Çağlar'ın yapmış olduğu ve toprakları sinıflandırırken morfolojisini de dikkate alarak oluşturduğu "Türkiye Toprak Haritası" nda 11 tane toprak grubuna yer vermiştir. (Dinç ve Şenol, 1987).

Coğrafi bölgelerde genellikle aşağıdaki toprak özellikleri topoğrafya ile ilgilidir. 1) Solumun derinliği, 2) A horizonunun kalınlığı ve organik madde içeriği, 3) Profilin oransal ıslaklığı, 4) Profilin rengi, 5) Horizon farklılaşmasının derecesi, 6) Toprak reaksiyonu, 7) Eriyebilir tuz miktarı, 8) Sert kat oluşunun derecesi ve çeşidi, 9) Sıcaklık, 10) 
Başlangıçtaki toprak materyalinin karakteristiği (Dinç ve Şenol, 1987).

Toprak bilimi araştırmaya açlk, sürekli güncelleme gerektiren ve teknolojik gelişmelere açık olan bir bilim dalıdır. Bu bilim dalının asıl amacı; toprağın doğal yapısını, özellikleri ve işlevlerini en iyi şekilde tanımlamaktır. Toprak hakkında güvenilir bilgi edinmek için toprak arazi üzerinde incelenmeli (morfolojisi ve diğer özellikleriyle) elde edilen bilgilerle tanımlanmalıdır. Toprağın tanımının iyi bir șekilde yapılması, arazi de yapılacak toprak örneklemelerindeki hata oranını düşürebilir. Toprak biliminin gelişmesi ve her yerde anlaşılması için ortak bir dil kullanmak gereklidir. Böylece toprakla ilgili yapılmış çalışmalar uluslararası düzeyde kabul görebilir (Gıda Tarım ve Hayvancılık Bakanlığı, 2013)

Süregelen haritalama metodlarında arazi üzerindeki bir noktaya ulaşmadaki doğruluk oranı daha az olmaktadır. Haritalama alanı içerisinde kalan tüm sınırların etüt esnasinda kontrolü sağlanamamaktadır. Birçok harita alanı sınırı, toprak özellikleri ve yer şekilleri özellikleri belirlenirken uzaydan yapılan gözlemler ve uzaktan algılama kullanılmaktadır (Shovic ve Mantagne, 1985).

Bilgisayarda depolanan bilgiler, farklı katmanların bir araya getirilmesiyle birçok bilgi tek katmanda toplanmaktadır. Bununla birlikte normal olarak kullanılan haritalardan elde edilemeyecek kadar fazla bilgi yalnızca tek bir sayısal harita sayesinde okunup ve değerlendirilebilmektedir. Ayrıca oluşturulmuş veri tabanıyla çok daha fazla sorgulama yapılabilmekte ve istenilen değerler hesaplanabilmektedir (Erdaş ve Gümüș, 2000).

Solmaz, (2010) Eğimi fazla olan arzilerde toprağın ayrıntılı bir şekilde haritalanmasını sağlamak amacıyla çalışmalar yapmıştır. Toprak etütünün daha hızlı zamanda ve daha az maliyetle bitirilmesi için yeni teknikler geliştirmek hedeflenmiştir. Adana Seyhan Barajı ile Çatalan Barajı arasında kalan alanda toprakların sınırlarını tespit etmek için yeni teknikler kullanmıştır. Toprakları arzi üzerinde tanımlamak için bilgisayara very girişi aktaran programlar hazırlamış ve kullanmıștır. Arazi çalışması öncesi toprak sınırlarını belirleyen sayısal haritalama tekniğinin istenilen oranda başarılı olamamıștır. Bunun sebebini ise çalıştıkları arazinin dağılımının homojen olmaması ve eksik verilerin fazla olması neden olmuştur.

Ünal, (2013) Araştırmacı çalışmasında gereç olarak $1 / 25000$ ölçekli topoğrafik haritalar ile havadan çekilen fotoğrafları kullanarak haritalarüretmiştir. Toprak profillerinden aldığı örneklerle yaptığı analizlerle iki adet toprak serisi tanımlamıştır. Toprak serilerine ait fazlar belirlemiştir. Arazi Kullanım Kabiliyeti, Sys Verheye ve Storie Endeks yöntemlerine göre arazi değerlendirilmesi yapmıştır. Elde ettiği verilere göre toprak haritaları oluşturmuştur.

Taş̧̧ı, (2015) Ardahan, Göle Platosu üzerinde bulunan çayır alanlarda olușan bitki örtüsünün alt kısımlarında oluşmuş toprak özelliklerini belirlemeyi hedeflemiştir. Arazide 4 adet profil açmış ve her bir profilin üç ayrı derinliğinden birer örnek almıştır. Yaptığı arazi çalışmaları ve laboratuvar analiz sonuçlarına göre; açtığı profillerin strüktürleri profilden aşağı doğru inildikçe kabalaşmıştır. Profilde alt horizonlara doğru inildikçe kök oranı ve organik madde miktarı azalmıştır. Profillerde kireç oranının düşük olduğunu tespit etmiş̧ir. Arazinin yüzeyinde organic madde ayrışması sonucu humus oluşmuştur. Toprak profillerinin renklerinin yukarıdan aşağı doğru inildikçe siyah renkten kahverengiye dönüştüğünü gözlemlemiștir.

Çelimli ve Ekinci, (2016) Tepearası-Eskiköy ovasında yaptıkları çalışmada toprakları toprak taksonomisine ve WRB'ye göre sinıflandırmalarını yapmışlar ve 3 adet seri tanımlamışlardır. Çalışmada topraklar toprak taksonomisine göre Entisol ve Inceptisol ordosuna, WRB'ye göre fluvisol ve Cambisol ordosuna dahil edilmiștir. Ayrıca araştırıcılar yaptıkları çalışmada topoğrafik haritalardan ve Google earth görüntüsü kullanarak detaylı toprak etüd ve haritalama yapmışlardır. Araştırıcılar çalışma alanının bitki besin elementi yönünden de değerlendirmesini yapmışlardır. Arazide drenaj problemleri tespit etmişler ve çözüm önerileri getirmişlerdir.

Şenol, (2017) Şenkaya, Gaziler yöresindeki toprakların özelliklerini çalışmıştır. Arazinin çeşitliği yerlerinden $0-20 \mathrm{~cm}$ derinlikten aldığ 17 toprak numunesini araştırması için kullanmıştır. Araziden aldığı toprak örneklerinin porozitesi, kıvam limitlerini, agregat stabilitesini, tekstürünü, organic maddesini, pH'sını, katyon değişim kapasitesini, toprağın nem karakterisliklerini ve hidrolik iletkenliğini belirlemiştir. Toprağın bu özelliklerini kullanarak yersel değişkenlik haritalarını hazırlamıștır.

Şimşek, (2018) Antalya'nın Aksu İlçesi'nin Solak Köyü tarım arazilerini toprak yönetimi açısından doğru bir şekilde kullanımını hedeflemiştir. Arazi 
çalışmaları sırasında 1/25000'lik topografik haritalar, geçmiş yıllara ait havadan çekilmiş fotoğraflar ve uydu görüntülerini kullanmıştır. Ayrıntılı șekilde yaptığı toprak etütlerine dayanarak laboratuvar analiz sonuçlarını da kullanarak "Arazi Yetenek Sınıflaması” yapmıștır. Yaptığı sınıflamaya göre çalışma arazisini kullanılabilir tarım arazisi kategorisine koymuştur. Ayrıca arazilerin kullanımı ile ilgili önerilerde bulunmuştur.

Everest ve ark. (2020) yaptıkları Gelibolu Namaztepe Bölgesindeki Farklı Fizyografyalar Üzerindeki Toprakların Bazı Fiziko-kimyasal Özellikleri ve Sınıflandırılması isimli çalışmada 3 profil açarak bunları toprak taksonomisine ve WRB'ye göre sınıflandırmışlarıdır. Araştırıcılar çalıșmayı Çanakkale ilinin Gelibolu ilçesinde Osmanlı İmparatorluğunun Rumeli bölgesine ilk çıkarma yaptığı Namaztepe mevkiinde aktif heyelan alanında yürütmüşlerdir. Çalışmada dikilitaş serisi, dereler serisi ve namaztepe serilerini tanımlamıșlardır. $\mathrm{Bu}$ serileri toprak taksonomisine göre sırasıyla Typic Haplusterts, Vertic Ustifluvents ve Typic Haplusterts olarak, WRB'ye göre Haplic Vertisols CalcaricHypereutric, Mollic Fluvisols Calcaric-HypereutricGleyic ve Haplic Vertisols Calcaric-Hypereutric olarak tanımlamışlardır.

Çalıșma alanımız olan Turnalık Yaylası, Ordu İli Kabadüz İlçesine bağlı il merkezine 47 km uzaklıkta olup Karadeniz Bölgesi'nin en meşhur yaylalarından biri olan Çambaşı Yaylası'na sınırdır.

Çambaşı Yaylası yolu üzerinde bulunan Turnalık Yaylası, ormanlarla kaplı çok geniş bir alanı kaplamaktadır. Ordu ilinin iklimsel olarak çok yağışlı ve kışların ılık geçmesi bitki örtüsü varlığının fazla olmasını sağlamaktadır. Kıyı şeridinde 1600 metre rakıma kadar ormanları hatta meyve ağaçlarını görmek mümkündür.

Çambaşı Yaylası'nın hızla yapılaşmaya başlaması ve yavaş yavaş yayla özelliğini kaybetmesiyle birlikte Turnalık Yaylası daha da fazla önem kazanmaktadır. Turnalık Yaylası hem doğal güzellikleri olsun hem de coğrafi konumu itibarıyla gelecekte yayla turizminin gelişmesinde Ordu İline büyük katkı sağlayacaktır.

Ordu ili Kabadüz İlçesi Turnalık Beldesinde deniz seviyesinden ortalama 1,450 m. yükseklikte yaklaşık $25 \mathrm{~km} 2$ alan içerisinde orman ve mer'a arazilerinde oluşan toprakların özelliklerinin belirlenerek oluşan toprakların sinıflandirılması amaciyla gerçekleștirilen bu çalışma orman ve mera örtüsü altında oluşan toprak gruplarını temsil edecek şekilde, farklı jeomorfolojik ve jeolojik birimler ile arazi örtüsü dikkate alınarak gerçekleștirilmiştir. Toprak olușturan faktörlerin tespitinde ve örnekleme yerlerinin belirlenmesinde uzaktan algılama ve coğrafi bilgi sistemleri kullanılmıștır.

\section{Materyal ve yöntem}

\section{Araştırma alanının yeri}

Araștırma yeri, Ordu ili Kabadüz ilçesi Turnalık beldesi topraklarının bir bölümünü kapsamaktadır (Şekil 1). Çalışma alanı 407687-412714m doğu ve 4502970-4507525m kuzey koordinatları arasında (ED_1950_UTM_Zone_37N, Transverse_Mercator) yer almaktadır.

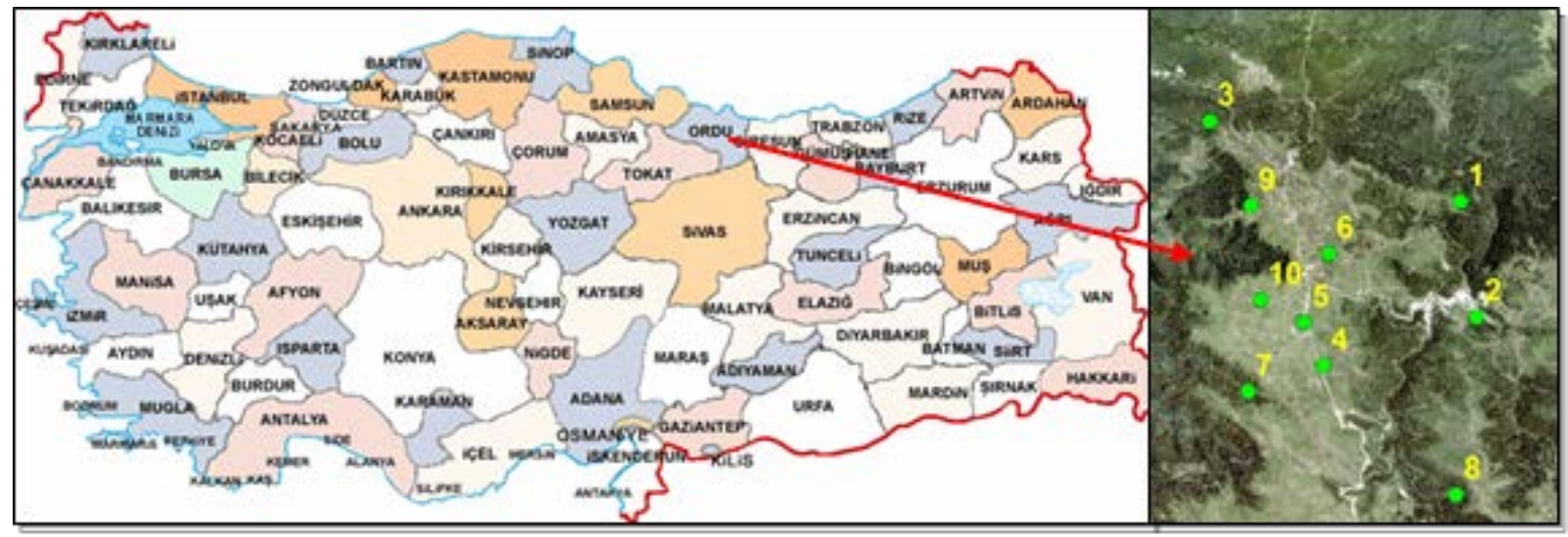

Şekil 1. Çalışma alanı lokasyon haritası ve örnekleme noktaları 


\section{Jeoloji}

Ordu il sınırları içinde kaya ve güncel (Kuvaterner yaşlı) çökellerden oluşan birimler yayılım göstermektedir. Çalışma alnında yayılım gösteren formasyonlar;

Çăglayan Formasyonu (Kç): Aybastı, Korgan, Kumru ilçeleri Tekkiraz beldesi ile Karadeniz arasında oldukça geniş bir alanda, volkanosedimenter özellikler taşıyan birime Güven 1993 yılında Çağlayan formasyonu adını verilmiştir.

Çağlayan formasyonu aglomera, tüfit, bazaltikandezitik lav, kumtaşı, silttaşı, çakıltaşı, kiltaşı, killi kireçtaşı ve kireçtaşından oluşur. Bu seviyeler çoğu yerde ardalanmalı, yanal ve düşey yönde birbiri ile geçişlidir. Formasyon içinde yer yer andezit, trakiandezit ve dasitik bileşimli dayklar (ayırtlanmamış) izlenir.

Formasyonun içinde daha yaygın izlenen aglomeralar koyu gri, kahverenkli, kırmızı, yeșilimsi gri renkli, tabakalanması, yer yer kalın tabakalı, çoğunlukla andezit, bazalt, seyrek olarak çört, volkanik kum taşı çakıllı ve blokludur. Tüfitler sarımsı gri, sarımsı yeşil renkli, ayrışmış seviyeleri mor, pembe renkli, yer yer andezit, bazalt çakıl serpintili, ince-orta-kalın tabakalı, bazen masif görünümlü, çoğunlukla gevşek tutturulmuştur. Aglomera ve tüfler yer yer çok ayrışmış olarak izlenir.

Aglomera-tüfit, andezitik-bazaltik lav ile kumtaşsilttaşı ara düzeylerinden oluşur. Aglomera-tüfit; yeșil, sarımsı gri, açık kahve renkli, masif, bazen kalın tabakalı, zayıf-orta sağlam dayanımlıdır. Lavlar; koyu gri, yeşil, kahve renkli, çok çatlaklı, eklemli, sağlam dayanımlıdır. Ara yüzey şeklinde izlenen kumtaşı-silttaşı: sarımsı gri, sarımsı yeșil renkli, orta-kalın tabakalı, gevşek-orta tutturulmuş, zayıforta sağlam dayanımlıdır.

Kaçkar Granitoyidi (\&k): Sarımsı gri, açık pembe renkli, sık eklemli, çatlaklı, sağlam-çok sağlam dayanımlı, granodiyorit-granitten oluşur (Ateş ve ark., 2004).

Jeolojik birimler ve çalışmada tanımlanan profil yerleri Şekil 2'de gösterilmiştir.

\section{Çalışmada kullanılan altlık materyaller ve} programlar

Çalışmada 1/25000'lik topoğrafik, 1/120000'lik jeolojik harita, 1/100000'lik Köy Hizmetleri Genel Müdürlüğü tarafından yapılan toprak haritasından ve spot 2015 uydu görüntülerinden yararlanılmıștır.

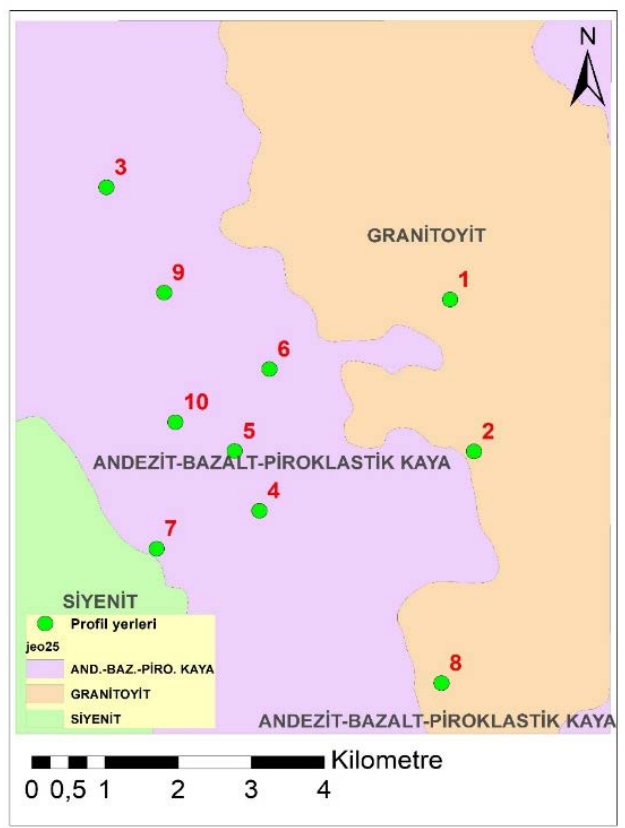

Şekil 1. Jeoloji haritası ve profil yerleri (1/25000 (Anonymous 2008))

\section{İklim}

Ordu ilinde, coğrafik konumu ile değişken topoğrafik özelliklerinden kaynaklanan iklimsel farklılıklar gözlenir. Kıyıya paralel olarak uzanan dağlar ile Karadeniz arasında kalan dar sahil kesiminde tipik Karadeniz iklimi görülür. Yazlar serin, kışlar ılık ve yağışlı geçer. Yılın bütün ayları yağışlı olmakla beraber, ilkbahar ayları az, sonbahar ayları çok yağışlıdır. Sahilden iç kesimlere doğru gidildiğinde, topoğrafyanın yükselmesi ve denizden uzaklaşmanın etkisiyle karasal iklime geçilir. $\mathrm{Bu}$ kesimde, kıyı kuşağına göre yazlar daha kurak, kışlar soğuk, karlı ve uzun olur. Çalışma alanındaki iklimsel farklılıklar uzun yıllar yağış ortalama değerlerine de yansımıștır. Uzun yıllar ortalamalarına göre il merkezinde yıllık ortalama yağış 1176.6 mm iken iç kesimlerde bu değer düşmektedir. Ulubey'de 990.9 mm/yıl, Aybastı'da 909.23 mm/yıl, Topçam'da 733.9 $\mathrm{mm} /$ yıl ve Mesudiye'de $541.8 \mathrm{~mm} / \mathrm{yll}$ 'dır. Topçam ve Mesudiye'nin yağış değerlerinin düşük olması bu kesimlerin karasal iklimin etkisinde olduğunu göstermektedir. Ordu merkezde sıcaklık $12.3{ }^{\circ} \mathrm{C}$, Ünye'de $14.3^{\circ}{ }^{\circ}$ 'dır. İç kesimlerde ise karasal iklimin etkisiyle sicaklık değerleri düşüş gösterir. Gölköyde sıcaklık ortalaması $8.1{ }^{\circ} \mathrm{C}$, Mesudiye'de ise $9.2^{\circ} \mathrm{C}$ 'ye düşer (Ateş ve ark., 2004).

Ordu ilinde topoğrafya kısa mesafelerde değişim göstermektedir. Yükseklik arttıkça yağışın azaldığı bilinmektedir. Ordu ilinde de yükseklik arttıkça yağış azalmıştır. Bayramin vd. (2008) yaptıkları çalışmada 
Türkiye'nin yağıș dağılım haritasını yapmışlardır. Bu haritaya göre ilin kuzeyinde yağış 900 mm'den daha fazla iken orta kesimlerde 750-900 mm, yüksek kesimlerde ise 600-750 $\mathrm{mm}$ düzeyindedir. (Türkmen, 2011). Bu çalışmanın gerçekleştiği orta kesimlerde yağıș $750 \mathrm{~mm}$ civarındadır.

Yıllık ortalama toprak sıcaklığının $8{ }^{\circ} \mathrm{C}$ 'den fazla fakat $15{ }^{\circ} C^{\prime}$ den düşük olması ve ortalama yaz sıcaklığı ile ortalama kıș sıcaklığı arasındaki farkın 6 'C'tan fazla olması nedeniyle toprak sicaklık rejimi mesic'tir. Normal yıllar içersinde, toprak nem rejimi kontrol kısmının tamamında, yaz gündönümünü takip eden 4 ay içersinde peşpeşe 45 gün veya daha fazla kuru ve kış gündönümünü takip eden 4 ay içersinde peşpeşe 45 gün veya daha fazla nemli ve normal ylllar içersinde, toprak nem rejimi kontrol kısmının bazı kesimleri, 50 cm'deki toprak sıcaklığının $6{ }^{\circ} \mathrm{C}$ 'nin üzerinde olan günlerin toplam olarak yarısından fazlasında nemli olması nedeniyle Soil Survey Staff. 1999'a göre toprak nem rejimi xeric'tir (Türkmen, 2011),

\section{Bilgisayar yazılımı}

$\begin{array}{lcrr}\text { Topoğrafik ve } & \text { Jeoloji } & \text { haritalarının } \\ \text { sayısallaştırılmasında, } & \text { profil } & \text { yerlerinin } \\ \text { gösterilmesinde } & \text { ARC GIS } & 9.3 .1 \text { yazılımı kullanılmıştır. }\end{array}$

\section{Yapılan analiz ve yöntemler}

\section{Yöntem}

Bu çalıșmada, ilk olarak Maden Tetkik ve Arama Genel Müdürlüğü'nden alınan 1: 25.000 ölçekli sayısal jeolojik haritalar kullanılarak farklı ana materyal ve farklı fizyoğrafik üniteler üzerinde bulunan topraklar belirlenmiştir. Tespit edilen farklı özellikteki topraklar üzerinde profil çukurlarının açlabilmesi için, Harita Genel Komutanlığı'ndan elde edilen 1: 25.000 ölçekli topoğrafik haritalardan yararlanılmış, ayrıca spot 2015 uydu görüntülerinden arazi kullanımı (orman ve mera) tespit edilerek toprak profil yerlerinin koordinatları belirlenmiş ve arazideki yerleri GPS aleti kullanarak kesin olarak tespit edilmiştir.

Çalışma alanında saptanan 10 farklı yerde (5 Orman arazisi 5 Mer'a arazisi) açllan profillerden genetik horizon esasına göre toplam 50 adet bozulmuş toprak örneği alınmış ve bu örnekler bazı ön işlemlerden geçirilerek, laboratuar analizlerine hazır hale getirilerek toprakların fiziksel, kimyasal özellikleri belirlenmiștir.

Çalışma alanındaki toprak profillerinin morfolojik olarak tanımlanması Soil Survey Staff (1993)'e göre yapılmıştır

\section{Fiziksel toprak analizleri}

Mekanik Analiz (Tekstür): Hidrometre yöntemi kullanılmıştır (Bouyoucous, 1951).

Hacim ağırlığı: Bozulmuş örnekler kullanılarak yapılmıştır (Blake ve Hartge 1986)

\section{Kimyasal toprak analizleri}

Değişebilir katyonlar: pH sı 8.2' ye ayarlı sodyum asetat (NaOAc) kullanılarak saptanmıştır (Rhoades, 1986).

Kireç: Serbest karbonatların tayininde Scheibler kalsimetresi kullanılmıştır. (Çağlar, 1958).

Toprak reaksiyonu (pH): Saturasyon çamuru ekstraktında cam elektrotlu $\mathrm{pH}$ metre kullanılarak belirlenmiștir (U.S.Salinity Laboratory 1954).

Elektriksel iletkenlik: Saturasyon çamuru ekstraktında kondaktivimetre aleti kullanılarak belirlenmiștir (U.S.Salinity Laboratory 1954).

Organik madde: Walkley-Black yönteminin Jackson tarafından modifiye edilmiş şekli ile belirlenmiştir (Jackson, 1958)

\section{Bulgular}

Toprak serilerinin bazı fiziksel, kimyasal ve morfolojik özellikleri

Çalıșma alanında arazi ve laboratuar çalışmaları sonucunda toplam 10 seri belirlenmiștir. Serilere ait fiziksel ve kimyasal analiz sonuçları Çizelge 1 ve Çizelge 2'de verilmiştir. Serilere ait özellikler ve taksonomik sınıflandırmaları aşağıda açıklanmıştır.

Kaleboynu Serisi: Yamaç arazilerde granitoyit üzerinde 1528 m'de orman örtüsü altında olușmuș, \% 10-20 eğime sahip, orta derinlikte olan bu topraklar taksonomik sınıflandırmaya göre Entisol ordosunun Typic Xerorthents alt grubuna girmektedir. Bu serideki topraklar hafif bünyeli olup yüzey horizonları kumlu tınlı alt horizonlar ise tın ve kil tın tekstüre sahiptir.

Taşbaşı Serisi: Yamaç arazilerde granitoyit üzerinde 1414 m'de, orman örtüsü altında oluşmuş, \% 5-10 eğime sahip, sığ olan bu topraklar taksonomik sinıflandırmaya göre Entisol ordosunun Typic Xerorthents alt grubuna girmektedir. Bu serideki topraklar hafif ve orta bünyeli olup yüzey horizonları tınlı alt horizonlar ise kumlu kil tınlı bünyeye sahiptir. Toprak pH'sı profilde 5,05-5,89 arasında değişim göstermektedir.

Arpalık Kırığı Serisi: Eğimi \%10-15 arasında olan, yamaç arazilerde Andezit-Bazalt-Prokilastik kaya üzerinde 1470 m'de Orman örtüsü altında oluşmuş, 
orta derinlikte olan bu topraklar mollik epipedona sahiptir ve taksonomik sınıflandırmaya göre Mollisol ordosunun Typic Haploxerolls alt grubuna girmektedir. Bu serideki topraklar hafif bünyeli olup kumlu tınlı bünyeye sahiptir.

Çıtlak Serisi: Așınım yüzeylerinde \%10-15 eğime sahip alanlarda Andezit-Bazalt-Prokilastik kaya üzerinde 1521 m'de mera örtüsü altında oluşan bu seri toprakları derindir. Mollic epipedona ve Argillic horizona sahip olan bu topraklar Taksonomik sinıflandırmaya göre Mollisol ordosunun Typic Argixerolls alt grubuna girmektedir. $\mathrm{Bu}$ serideki topraklar hafif ve orta bünyeli olup yüzey horizonları kumlu tınlı, alt horizonlar ise kil artışı ile birlikte kumlu kil tın bünyeye sahiptir.

Köklücedibi Serisi: Așınım yüzeylerinde, AndezitBazalt-Prokilastik kaya üzerinde oluşmuş, \% 10-15 eğime sahip, derin olan bu topraklar 1472 m'de mera örtüsü altında oluşmuştur. Argillic horizona sahip olan bu topraklar taksonomik sinıflandırmaya göre Alfisol ordosunun Mollic Haploxeralfs alt grubuna girmektedir. $\mathrm{Bu}$ serideki toprakların yüzey horizonları hafif bünyeli, kumlu tın olup yüzey altı horizonları kil artışı ile birlikte kumlu kil tınlı tekstüre sahiptir.

Yenioba Serisi: Andezit-Bazalt-Prokilastik kaya üzerinde ve aşınım yüzeylerinde 1475 m'de mera örtüsü altında oluşmuş olan bu seri toprakları, \% 1015 eğime sahip, orta derinliktedir. $\mathrm{Bu}$ topraklar Mollic epipedona ve Cambic horizona sahip olduklarından taksonomik sinıflandırmaya göre Mollisol ordosunun Typic Haploxerolls alt grubuna girmektedir. Bu serideki topraklar hafif bünyeli olup kumlu tınlı tekstüre sahiptir.

Susuz Serisi: Eğimi \%10-15 arasında olan, aşınım yüzeylerinde, Andezit-Bazalt-Prokilastik kaya üzerinde oluşmuş, orta derinlikte olan bu topraklar 1528 m’de Orman örtüsü altında oluşmuşlardır. Az gelişmiş olan A-C horizonlu bu topraklar yalnızca Ochric epipedona sahip olduklarından taksonomik sinıflandırmaya göre Entisol ordosunun Typic Xerorthents alt grubuna girmektedir. $\mathrm{Bu}$ serideki toprakların kum değerleri \% 65'in üzerinde olduğundan hafif bünyeli olup yüzey horizonları kumlu tın, alt horizonlar ise tınlı kum tekstüre sahiptir.

Duyuyalak Tepe Serisi: Așınım yüzeylerinde, granitoyit üzerinde oluşmuş, \% 30'dan daha fazla eğime sahip, sığ derinlikte olan bu topraklar 1670 m'de Orman örtüsü altında oluşmuşlardır. Derinlikleri 50 cm'den az olan bu topraklar tanımlama horizonu olarak yalnızca Ochric epipedona sahip olduklarından taksonomik sinıflandırmaya göre Entisol ordosunun Lithic Xerorthents alt grubuna girmektedir. $\mathrm{Bu}$ serideki topraklar hafif bünyeli olup bütün horizonları kumlu tınlı tekstüre sahiptir.

Nasif Tepe Serisi: Yamaç arazilerde Andezit-BazaltProkilastik kaya üzerinde oluşmuş, \% 30'dan daha fazla eğime sahip, orta derinlikte olan bu topraklar 1500 m’de mera örtüsü altında oluşmuştur. Mollic epipedon ve Argillic horizona sahip olan bu topraklar taksonomik sinıflandırmaya göre Mollisol ordosunun Typic Argixerolls alt grubuna girmektedir. Bu serideki topraklar hafif bünyeli olup yüzey horizonları kumlu tınlı alt horizonlar ise kumlu kil tın tekstüre sahiptir.

Gölardı Serisi: Yamaç arazilerde Andezit-BazaltProkilastik kaya üzerinde oluşmuş, \% 10-15 eğime sahip, sığ derinlikte olan bu topraklar 1507 m'de mera örtüsü altında A-C horizonlu genç topraklar olmasına rağmen yüzeyde iyi gelişmiş bir Mollic epipedona sahip olduklarından taksonomik sinıflandırmaya göre Mollisol ordosunun Typic Haploxerolls alt grubuna girmektedir. $\mathrm{Bu}$ serideki topraklar hafif bünyeli olup yüzey horizonları kumlu tın, alt horizonlar ise kumlu kil tın tekstüre sahiptir.

Çalışma alanı topraklarında tuzluluk gözlenmemiş ve kireç oranı da \%1'in altında belirlenmiştir. pH değerlerin ise 4.19 ile 6.21 arasında değişim gösterdiği tespit edilmiştir.

\section{Tartışma ve Sonuç}

$\mathrm{Bu}$ çalışmada Ordu İli, Kabadüz İlçesi Turnalık Beldesinde 5 adet mer'a alanlarından, 5 adet orman alanlarından olmak üzere toplam 10 adet profil açılmıştır. Bu profillerden toplam 50 adet örnek alınmış ve bu örneklerde gerekli analizler yapılarak topraklar Soil Taxonomy 1999'a göre sınıflandırılmıştır. Yapılan çalışma sonucunda Entisol, Alfisol ve Mollisol olmak üzere 3 farklı ordo ve bu ordolara ait 3 Alt ordo, 4 Büyük grup ve 5 Alt grup belirlenmiștir (Çizelge 3). Ordu ilinde Türkmen (2011) tarafından yapılan çalışmada da Entisol, Alfisol, Mollisol ordolarının yanı sira Inceptisol, Vertisol ordoları da tanımlanmıștır. 
Çizelge 1. Araştırma alanına ait toprakların fiziksel analiz sonuçları

\begin{tabular}{|c|c|c|c|c|c|c|c|c|}
\hline Horizon & Derinik & Renk Kuru. Nemli & $\%$ Kil & $\%$ Silt & $\%$ Kum & Tekstür & $\begin{array}{c}\text { Organik } \\
\text { Madde (\%) }\end{array}$ & $\begin{array}{c}\text { H.A. } \\
\left(\mathrm{g} / \mathrm{cm}^{3}\right)\end{array}$ \\
\hline \multicolumn{9}{|c|}{ Kaleboynu Serisi } \\
\hline $\mathrm{Oa}$ & $0-7$ & & & & & & & \\
\hline $\mathrm{A} 1$ & $0-17$ & 10YR4/2. 10YR3/2 & 14.58 & 20.06 & 65.36 & Kumlu Tin & 12.21 & 0.69 \\
\hline $\mathrm{A} 2$ & $17-38$ & 10YR6/3. 10YR3/3 & 14.99 & 29.12 & 55.88 & Kumlu Tin & 5.70 & 0.89 \\
\hline $\mathrm{AC}$ & $38-51$ & 10YR7/3. 10YR4/3 & 14.78 & 31.40 & 53.82 & Tin & 3.52 & 1.02 \\
\hline $\mathrm{C}$ & $51-75$ & 10YR8/3. 10YR5/4 & 28.88 & 29.24 & 41.87 & Kumlu Kil Tın & 0.53 & 1.29 \\
\hline \multicolumn{9}{|c|}{ Taşbaşı Serisi } \\
\hline 0 & $0-4$ & & & & & & & \\
\hline $\mathrm{A} 1$ & $0-14$ & 10YR5/3. 10YR3/3 & 19.02 & 30.00 & 50.98 & Tin & 8.01 & 0.88 \\
\hline $\mathrm{A} 2$ & $14-31$ & 10YR5/3. 10YR3/3 & 21.39 & 24.54 & 54.08 & Kumlu Kil Tın & 5.36 & 1.04 \\
\hline $\mathrm{C} 1$ & $26-68$ & 10YR6/4. 10YR4/4 & 25.32 & 17.92 & 56.76 & Kumlu Kil Tın & 1.50 & 1.12 \\
\hline $\mathrm{C} 2$ & $68-100$ & 10YR7/4. 10YR4/4 & 21.37 & 18.02 & 60.60 & Kumlu Kil Tın & 0.80 & 1.28 \\
\hline $\mathrm{C} 3$ & $100-135$ & 10YR6/4. 10YR4/4 & 20.88 & 14.22 & 64.90 & Kumlu Kil Tın & 0.50 & 1.34 \\
\hline $\operatorname{Cg} 4$ & $135+$ & 10YR7/4. 10YR4/6 & 20.86 & 14.21 & 64.93 & Kumlu Kil Tin & 0.43 & 1.31 \\
\hline \multicolumn{9}{|c|}{ Arpalık Kırı̆̆ı serisi } \\
\hline 0 & $0-4$ & & & & & & & \\
\hline $\mathrm{A} 1$ & $0-17$ & 10YR5/3. 10YR3/3 & 11.07 & 22.68 & 66.26 & Kumlu Tin & 12.55 & 0.74 \\
\hline A2 & $17-31$ & 10YR4/3. 10YR3/3 & 13.33 & 22.96 & 63.71 & Kumlu Tin & 8.82 & 0.81 \\
\hline $\mathrm{AC}$ & $31-53$ & 10YR5/4. 10YR3/3 & 19.40 & 22.62 & 57.97 & Kumlu Tın & 5.43 & 0.88 \\
\hline $\mathrm{C} 1$ & $53-74$ & 10YR6/4. 10YR3/4 & 27.22 & 26.28 & 46.50 & Kumlu Kil Tın & 2.04 & 0.95 \\
\hline $\mathrm{Cr}$ & $74-105$ & & & & & & & \\
\hline \multicolumn{9}{|c|}{ Çıtlak Serisi } \\
\hline $\mathrm{A} 1$ & $0-9$ & 10YR5/3. 10YR3/3 & 15.22 & 27.17 & 57.61 & Kumlu Tin & 6.51 & 0.92 \\
\hline $\mathrm{A} 2$ & $9-25$ & 10YR5/3. 10YR3/3 & 17.23 & 24.97 & 57.80 & Kumlu Tin & 3.39 & 0.95 \\
\hline $\mathrm{Bt}$ & $25-54$ & 10YR5/4. 10YR4/4 & 25.24 & 22.24 & 52.52 & Kumlu Kil Tın & 1.76 & 1.06 \\
\hline $\mathrm{C} 1$ & $54-72$ & 10YR6/4. 10YR3/4 & 31.27 & 18.42 & 50.31 & Kumlu Kil Tın & 0.47 & 1.16 \\
\hline $\mathrm{C} 2$ & $72-120$ & 10YR6/4. 10YR4/4 & 29.66 & 20.77 & 49.57 & Kumlu Kil Tın & 0.27 & 1.00 \\
\hline \multicolumn{9}{|c|}{ Köklücedibi Serisi } \\
\hline A1 & $0-14$ & 10YR4/3. 10YR3/3 & 5.99 & 23.37 & 70.64 & Kumlu Tin & 8.91 & 0.88 \\
\hline $\mathrm{A} 2$ & $14-26$ & 10YR5/3. 10YR3/3 & 15.96 & 26.54 & 57.50 & Kumlu Tın & 3.44 & 1.07 \\
\hline Bt1 & $26-55$ & 10YR6/4. 10YR4/4 & 22.03 & 20.36 & 57.61 & Kumlu Kil Tın & 0.27 & 1.21 \\
\hline Bt2 & $55-84$ & 10YR6/4. 10YR4/4 & 26.16 & 18.36 & 55.48 & Kumlu Kil Tın & 0.41 & 1.19 \\
\hline Bt3 & 84-108 & 10YR6/4. 10YR4/4 & 25.92 & 20.87 & 53.21 & Kumlu Kil Tın & 1.00 & 1.18 \\
\hline $\mathrm{C}$ & $108-130$ & 10YR6/3. 10YR4/3 & 20.03 & 18.70 & 61.26 & Kumlu Kil Tın & 0.73 & 1.09 \\
\hline \multicolumn{9}{|c|}{ Yenioba Serisi } \\
\hline A1 & $0-11$ & 10YR5/2.10YR3/2 & 15.73 & 28.09 & 56.18 & Kumlu Tin & 7.54 & 0.89 \\
\hline A2 & $11-28$ & 10YR5/2. 10YR3/2 & 15.63 & 30.33 & 54.04 & Kumlu Tin & 6.34 & 0.92 \\
\hline A3 & $28-42$ & 10YR5/2.10YR3/2 & 19.67 & 23.75 & 56.57 & Kumlu Tın & 2.60 & 1.01 \\
\hline Bw & $42-68$ & 10YR6/2.10YR4/2 & 21.77 & 23.81 & 54.42 & Kumlu Kil Tın & 0.73 & 1.27 \\
\hline $\mathrm{C}$ & 68-78 & 10YR6/2. 10YR4/2 & 19.70 & 12.84 & 67.46 & Kumlu Tin & 0.60 & 1.25 \\
\hline \multicolumn{9}{|c|}{ Susuz Serisi } \\
\hline 0 & $0-7$ & & & & & & & \\
\hline $\mathrm{A} 1$ & $0-13$ & 10YR4/2. 10YR3/2 & 11.79 & 19.41 & 68.80 & Kumlu Tin & 15.49 & 0.68 \\
\hline $\mathrm{A} 2$ & $13-32$ & 10YR5/3. 10YR3/3 & 13.62 & 21.08 & 65.30 & Kumlu Tin & 11.08 & 0.84 \\
\hline $\mathrm{C} 1$ & $32-51$ & 10YR7/4. 10YR4/6 & 11.44 & 2.60 & 85.96 & Tınlı Kum & 0.93 & 1.15 \\
\hline $\mathrm{C} 2$ & $51-98$ & 10YR7/3. 10YR4/4 & 7.34 & 10.65 & 82.00 & Tinlı Kum & 0.40 & 1.25 \\
\hline \multicolumn{9}{|c|}{ Duyuyalak Tepe Serisi } \\
\hline 0 & $0-4$ & & & & & & & \\
\hline $\mathrm{A}$ & $0-16$ & 10YR7/2.10YR5/3 & 19.51 & 21.90 & 58.59 & Kumlu Tin & 3.34 & 1.03 \\
\hline $\mathrm{AC}$ & $16-31$ & 10YR7/3. 10YR5/3 & 19.48 & 21.87 & 58.65 & Kumlu Tin & 2.27 & 1.08 \\
\hline C & $31-47$ & 10YR7/3. 10YR5/4 & 19.49 & 17.83 & 62.68 & Kumlu Tin & 1.27 & 1.10 \\
\hline $\operatorname{Cr} 47-58$ & 47-58 & & & & & & & \\
\hline \multicolumn{9}{|c|}{ Nasif Tepe Serisi } \\
\hline A1 & $0-10$ & 10YR4/3. 10YR3/3 & 16.31 & 8.16 & 75.53 & Kumlu Tin & 11.21 & 0.72 \\
\hline $\mathrm{A} 2$ & $10-20$ & 10YR5/3. 10YR3/3 & 15.78 & 20.29 & 63.93 & Kumlu Tin & 4.74 & 0.95 \\
\hline Bt1 & $20-37$ & 10YR6/3. 10YR3/4 & 21.64 & 21.64 & 56.72 & Kumlu Kil Tın & 1.86 & 1.13 \\
\hline $\mathrm{Bt} 2$ & $37-68$ & 10YR6/3. 10YR4/3 & 21.62 & 18.86 & 59.51 & Kumlu Kil Tın & 0.66 & 1.26 \\
\hline $\mathrm{C}$ & $68-97$ & 10YR7/3. 10YR5/4 & 17.57 & 14.81 & 67.62 & Kumlu Tın & 0.60 & 1.26 \\
\hline \multicolumn{9}{|c|}{ Gölardı Serisi } \\
\hline A1 & $0-7$ & 10YR4/3. 10YR3/2 & 5.46 & 27.48 & 67.05 & Kumlu Tin & 12.21 & 0.76 \\
\hline $\mathrm{A} 2$ & $7-17$ & 10YR5/3. 10YR3/3 & 17.72 & 25.19 & 57.08 & Kumlu Tın & 4.84 & 0.91 \\
\hline $\mathrm{AC}$ & $17-35$ & 10YR6/4. 10YR4/4 & 23.84 & 25.15 & 51.02 & Kumlu Kil Tın & 2.72 & 0.96 \\
\hline $\mathrm{C} 1$ & $35-58$ & 10YR6/4. 10YR4/4 & 25.75 & 18.91 & 55.34 & Kumlu Kil Tın & 1.19 & 1.11 \\
\hline $\mathrm{C} 2$ & $58-90$ & 10YR6/4. 10YR4/4 & 27.91 & 21.04 & 51.05 & Kumlu Kil Tın & 1.19 & 1.17 \\
\hline
\end{tabular}


Çizelge 2. Araştırma alanına ait toprakların kimyasal analiz sonuçları

\begin{tabular}{|c|c|c|c|c|c|c|c|c|}
\hline Horizon & Derinlik & EC (mikroS/cm) & $\mathrm{pH}(1 / 2.5)$ & \% Kireç & $\mathrm{Ca}(\mathrm{mg} / \mathrm{L})$ & $\mathrm{Mg}(\mathrm{mg} / \mathrm{L})$ & $\begin{array}{c}\mathrm{Na} \\
(\mathrm{mg} / \mathrm{L})\end{array}$ & $\mathrm{K}(\mathrm{mg} / \mathrm{L})$ \\
\hline \multicolumn{9}{|c|}{ Kaleboynu Serisi } \\
\hline $\mathrm{Oa}$ & $0-7$ & & & & & & & \\
\hline $\mathrm{A} 1$ & $0-17$ & 83.30 & 5.18 & 0.33 & 65.30 & 8.95 & 1.55 & 45.70 \\
\hline $\mathrm{A} 2$ & $17-38$ & 95.30 & 5.36 & 0.66 & 52.86 & 2.78 & 1.07 & 21.29 \\
\hline $\mathrm{AC}$ & $38-51$ & 95.40 & 4.90 & 0.41 & 48.87 & 1.72 & 0.88 & 12.84 \\
\hline $\mathrm{C}$ & $51-75$ & 38.70 & 5.22 & 0.24 & 43.69 & 4.55 & 0.95 & 6.13 \\
\hline \multicolumn{9}{|c|}{ Tașbașı Serisi } \\
\hline 0 & $0-4$ & & & & & & & \\
\hline $\mathrm{A} 1$ & $0-14$ & 42.40 & 5.05 & 0.49 & 73.40 & 9.32 & 0.49 & 55.60 \\
\hline $\mathrm{A} 2$ & $14-31$ & 48.50 & 5.25 & 0.33 & 56.40 & 0.73 & 0.34 & 26.08 \\
\hline $\mathrm{C} 1$ & $26-68$ & 18.43 & 5.55 & - & 56.98 & 2.59 & 0.20 & 7.10 \\
\hline $\mathrm{C} 2$ & $68-100$ & 16.96 & 5.51 & 0.16 & 116.38 & 2.90 & 0.44 & 9.45 \\
\hline $\mathrm{C} 3$ & $100-135$ & 14.18 & 5.67 & 0.16 & 111.54 & 19.00 & 0.90 & 16.12 \\
\hline $\mathrm{Cg} 4$ & $135+$ & 14.52 & 5.89 & - & 187.33 & 21.78 & 1.15 & 15.20 \\
\hline \multicolumn{9}{|c|}{ Arpalık Kırığı serisi } \\
\hline 0 & $0-4$ & & & & & & & \\
\hline $\mathrm{A} 1$ & $0-17$ & 42.90 & 5.43 & - & 55.36 & 13.19 & 0.78 & 46.39 \\
\hline $\mathrm{A} 2$ & $17-31$ & 25.90 & 5.56 & 0.16 & 70.40 & 5.93 & 0.67 & 39.82 \\
\hline $\mathrm{AC}$ & $31-53$ & 17.53 & 5.58 & 0.07 & 73.63 & 4.60 & 0.10 & 40.60 \\
\hline $\mathrm{C} 1$ & $53-74$ & 18.17 & 5.45 & - & 86.58 & 5.90 & 0.34 & 50.85 \\
\hline $\mathrm{Cr}$ & $74-105$ & & & & & & & \\
\hline \multicolumn{9}{|c|}{ Citlak Serisi } \\
\hline A1 & $0-9$ & 28.00 & 5.64 & & 84.02 & 1.09 & 0.56 & 37.18 \\
\hline $\mathrm{A} 2$ & $9-25$ & 15.92 & 5.92 & 0.16 & 64.91 & 16.94 & 0.69 & 14.53 \\
\hline $\mathrm{Bt}$ & $25-54$ & 14.54 & 6.11 & 0.16 & 65.18 & 15.73 & 0.83 & 24.39 \\
\hline $\mathrm{C} 1$ & $54-72$ & 11.82 & 6.16 & 0.16 & 42.77 & 15.49 & 1.17 & 91.20 \\
\hline $\mathrm{C} 2$ & $72-120$ & 12.37 & 6.21 & 0.24 & 54.95 & 34.00 & 1.35 & 52.95 \\
\hline \multicolumn{9}{|c|}{ Köklücedibi Serisi } \\
\hline A1 & $0-14$ & 23.70 & 5.76 & - & 123.97 & 66.31 & 0.86 & 28.72 \\
\hline $\mathrm{A} 2$ & $14-26$ & 16.86 & 5.91 & - & 85.90 & 29.16 & 0.85 & 21.37 \\
\hline Bt1 & $26-55$ & 10.77 & 6.06 & 0.16 & 18.43 & 28.92 & 0.78 & 8.44 \\
\hline Bt2 & $55-84$ & 10.63 & 6.07 & 0.07 & 52.81 & 24.20 & 0.68 & 7.77 \\
\hline Bt3 & 84-108 & 10.87 & 6.03 & 0.07 & 94.31 & 18.15 & 1.23 & 11.07 \\
\hline $\mathrm{C}$ & $108-130$ & 13.77 & 5.93 & - & 125.07 & 50.94 & 1.38 & 10.07 \\
\hline \multicolumn{9}{|c|}{ Yenioba Serisi } \\
\hline A1 & $0-11$ & 27.20 & 5.55 & - & 83.83 & 13.92 & 1.67 & 21.25 \\
\hline $\mathrm{A} 2$ & $11-28$ & 25.20 & 5.65 & - & 59.85 & 3.27 & 1.86 & 11.87 \\
\hline $\mathrm{A} 3$ & $28-42$ & 17.00 & 5.74 & - & 70.94 & 3.51 & 2.23 & 6.04 \\
\hline Bw & $42-68$ & 13.00 & 6.03 & - & 66.68 & 26.86 & 3.71 & 5.39 \\
\hline $\mathrm{C}$ & $68-78$ & 13.13 & 6.12 & - & 69.09 & 35.94 & 5.57 & 4.83 \\
\hline \multicolumn{9}{|c|}{ Susuz Serisi } \\
\hline 0 & $0-7$ & & & & & & & \\
\hline $\mathrm{A} 1$ & $0-13$ & 78.80 & 4.19 & - & 61.56 & 5.20 & 0.89 & 35.76 \\
\hline $\mathrm{A} 2$ & $13-32$ & 35.30 & 4.73 & 0.07 & 56.64 & 2.18 & 0.80 & 21.40 \\
\hline $\mathrm{C} 1$ & $32-51$ & 16.37 & 5.13 & - & 63.02 & 9.44 & 0.39 & 6.19 \\
\hline $\mathrm{C} 2$ & $51-98$ & 14.13 & 5.33 & - & 110.00 & 1.94 & 0.30 & 6.92 \\
\hline \multicolumn{9}{|c|}{ Duyuyalak Tepe Serisi } \\
\hline 0 & $0-4$ & & & & & & & \\
\hline $\mathrm{A}$ & $0-16$ & 51.70 & 4.81 & - & 57.23 & 10.89 & 0.85 & 35.06 \\
\hline $\mathrm{AC}$ & $16-31$ & 81.50 & 5.19 & - & 73.62 & 5.93 & 1.01 & 36.15 \\
\hline C & $31-47$ & 27.30 & 5.32 & - & 66.06 & 9.32 & 0.79 & 22.51 \\
\hline $\operatorname{Cr} 47-58$ & $47-58$ & & & & & & & \\
\hline R 58+ & $58+$ & & & & & & & \\
\hline \multicolumn{9}{|c|}{ Nasif Tepe Serisi } \\
\hline $\mathrm{A} 1$ & $0-10$ & 29.50 & 5.50 & - & 88.41 & 29.52 & 2.13 & 29.69 \\
\hline $\mathrm{A} 2$ & $10-20$ & 16.91 & 5.73 & - & 73.45 & 18.39 & 2.48 & 13.28 \\
\hline Bt1 & $20-37$ & 15.67 & 5.79 & - & 55.08 & 14.16 & 1.81 & 5.94 \\
\hline Bt2 & $37-68$ & 11.08 & 5.95 & - & 98.54 & 20.81 & 1.68 & 5.39 \\
\hline $\mathrm{C}$ & $68-97$ & 10.92 & 5.94 & - & 30.23 & 15.25 & 1.72 & 6.76 \\
\hline \multicolumn{9}{|c|}{ Gölardı Serisi } \\
\hline A1 & $0-7$ & 33.90 & 5.64 & - & 135.52 & 40.29 & 1.46 & 46.16 \\
\hline $\mathrm{A} 2$ & $7-17$ & 18.95 & 5.85 & - & 63.05 & 31.82 & 1.54 & 13.72 \\
\hline $\mathrm{AC}$ & $17-35$ & 16.41 & 6.03 & - & 109.42 & 36.42 & 1.57 & 8.37 \\
\hline $\mathrm{C} 1$ & $35-58$ & 13.22 & 6.17 & - & 38.09 & 34.00 & 2.04 & 9.17 \\
\hline $\mathrm{C} 2$ & $58-90$ & 13.37 & 6.06 & - & 95.32 & 50.22 & 3.37 & 11.42 \\
\hline
\end{tabular}


Çizelge 3. Çalışma alanı topraklarının Soil Taxonomy’e göre dağılımları

\begin{tabular}{|c|c|c|c|c|c|}
\hline $\begin{array}{c}\text { Arazi } \\
\text { Kullanımı }\end{array}$ & Seri adı & Ordo & Altordo & Büyük grup & Alt grup \\
\hline \multirow{5}{*}{ Orman } & Kaleboynu & \multirow{4}{*}{ Entisol } & Orthents & Xerorthents & Typic Xerorthents \\
\hline & Taşbașı & & Orthents & Xerorthents & Typic Xerorthents \\
\hline & Susuz & & Orthents & Xerorthents & Typic Xerorthents \\
\hline & Duyuyalak Tepe & & Orthents & Xerorthents & Lithic Xerorthents \\
\hline & Arpalık Kırığı & \multirow{5}{*}{ Mollisol } & Xrerolls & Haploxrerolls & Typic Haploxerolls \\
\hline \multirow{5}{*}{ Mer'a } & Yenioba & & Xerolls & Haploxerolls & Typic Haploxerolls \\
\hline & Gölardı & & Xerolls & Argixerolls & Typic Haploxerolls \\
\hline & Nasif Tepe & & Xerolls & Argixerolls & Typic Argixerolls \\
\hline & Çıtlak & & Xerolls & Haploxerolls & Typic Argixerolls \\
\hline & Köklücedibi & Alfisol & Xeralfs & Haploxeralfs & Mollic Haploxeralfs \\
\hline
\end{tabular}

Yapılan çalışmada toprakların genellikle kumlu tınlı ve kumlu kil tın bünyeye sahip olduğu görülmüştür. Toprakların kum içeriği \%41,87-85,96 arasında değişmiştir. Kil içerikleri ise \%5,46-31,27 arasında değişim göstermiştir. Bu bizleri toprakların oluşum açısından genç olduklarını, ayrışma sürecinin başında olduklarını göstermektedir. Ayrıca yapılan profil tanımlamalarında profillerin 6 tanesisin A-C horizonlu genç topraklar olduğu görülmektedir. Yine çalışmada elde edilen verilere göre bir profil A-Bw-C horizonlu bulunmuştur. Bu horizon dizilimi de yine toprakların genç olduğunun bir göstergesidir. Çalışmada geriye kalan 3 profil ise A-Bt-C horizonlu tanımlanmıș olup bunların olgun topraklar olduğu tespit edilmiştir. Burada dikkati çeken nokta arazinin eğimli olması, yamaç ve aşınma yüzeylerinden oluşmasıdır. Bu yüzeylerde oluşan topraklar daha düz, taban arazilere taşındığı için bu alanlarda oluşan topraklar genç ve sığ oluşum göstermiștir. Birikim noktalarında ise toprakların daha derin ve olgun topraklar olduğu görülmektedir.

Toprakların $\mathrm{pH}$ içerikleri incelendiğinde genellikle düşük pH'lara rastlanmaktadır. $\mathrm{pH}$ değerleri 4,196,21 arasında değişim göstermektedir. Yüzey horizonu olan ve bitkilerin kök gelişiminin ve biyolojik aktivitenin en fazla olduğu A horizonunda organik madde değerleri \%2,26-15-48 arasında değişmektedir. Organik maddenin yüksek olması bölgenin sıcaklık ortalamasının düșük olmasından ve arazi kullanımının Orman ve Mer'a olmasından kaynaklanmaktadır. Orman ve mer'a örtüsü altında organik maddenin biriktiği bilinmektedir.

$\mathrm{Bu}$ çalışmada Orman örtüsü ile kaplı alanlarda yüzeyde organik maddenin birikmiş olduğu 0 horizonu tanımlanmıștır. Bu horizonun oluşabilmesi için toprağa düșen organik materyalin toprak canlıları tarafından parçalanıp toprağa karışmaması gerekir. Burada birikim olması sıcaklık şartlarının biyolojik aktiviteyi sınırlandıracak düzeylerde olduğunun bir göstergesidir.

Çalıșmada profillerin genellikle orta ve sığ derinlikte oldukları belirlenmiștir. A-C horizonlu toprakların solum olarak ifade ettiğimiz ası toprak derinliklerinin $50 \quad \mathrm{~cm}$ 'den daha az olduğu belirlenmiştir. Ancak B horizonuna sahip profillerin toprak derinlikleri $50 \mathrm{~cm}$ 'nin üzerinde çıkmıştır. Topraklarda Lithic Contact dediğimiz 50 cm'ye kadar ana kayaya yalnızca bir profilde rastlanmıștır. Diğer profillerde ise anakayanın alterasyona uğradığı fakat toprak oluşacak kadar zamanın geçmediği, üzerinde toprak oluşumunu sağlayan anamateryalin derin olduğu tespit edilmiştir.

Yapılan analizler neticesinde bölgede tuzluluk problemine rastlanılmamıștır. $\mathrm{Bu}$ sonuç bizlere bölgede drenajı kapalı yerlerin olmadığını, toprak içi drenajın iyi olduğunu göstermektedir. Bölge geneli itibariyle ondüleli bir topoğrafyaya sahiptir ve drenaj problemi görülmemektedir. Bölgede kireç miktarı \%1'in altında tespit edilmiștir. Bölge topraklarının $\mathrm{pH}$ değerlerinin düşük olması bu sonucu desteklemektedir.

\section{Sonuç}

Yapılan çalıșma sonucunda bölge topraklarının oluşum ve ayrışma süreci bakımından genç topraklar olduğu görülmektedir. Bunun sonucu olarak toprakların fazla derin olmaması, eğimin fazla olması nedeniyle yapılacak herhangi bir kültürel uygulamanın mutlaka toprak koruma önlemleri alınarak yapılması gerektiği, eğimin arttığı yerlerde mevcut arazi örtüsünün korunmasının daha uygun olacağl, toprak erozyonu ve toprakların sürdürülebilir kullanımı açısından bu faktörlerin dikkate alınmasının çok önemli olduğu tespit edilmiştir. 


\section{Teşekkür}

Bu çalışma Ordu Üniversitesi BAP birimi tarafından TF-1637 nolu proje ile desteklenmiştir. Teşekkürlerimizi sunarız.

\section{Kaynaklar}

Anonymous, (2008). Ordu ili sayısal 1:25000'lik jeoloji haritası. Maden Tetkik ve Arama Genel Müdürlüğü, Ankara.

Ateș, Ş., Keçer, M., Mutlu. G., Bulut. A., Osmançelebioğlu. R., Özberk. O. C., Özata. A., Şule. S., \& Karakaya. F. (2004). Ordu İlinin Yer Bilim Verileri ve Doğal Afet Özellikleri. M.T.A. Genel Müdürlüğü Jeoloji Etüdleri Dairesi, Ankara.

Bayramin, İ., Erpul, E., Öztürk, H.S., Erdoğan, E., Uğurlu, A., \& Kesim A. (2008). Türkiye'de erozyon olușturma gücünü gösteren yă̆ış indislerinin belirlenmesi. TOVAG 1040444. TÜBITTAK projesi.

Blake, G.R. \& Hartge. K.H. (1986). Bulk Density and Particle Density. In : Methods of Soil Analysis, Part I, Physical and Mineralogical Methods. Pp: 363-381. ASA and SSSA Agronomy Monograph no 9(2nd $e d)$, Madison.

Bouyoucous, G.J. (1951). A Recalibration of Hydrometer for Making Mechanical Analysis of Soils. Agronomy Journal, 43, 9.

Çağlar, K.ö. (1958). Toprak İlmi. AÜ Ziraat Fakültesi yayınları, No:10 Ankara

Çelimli, S. K., \& Ekinci, H. (2016). Tepearası - Eskiköy (Köyceğiz) Yöresi Topraklarının Detaylı Toprak Etüt Haritalanması - Sinıflandırılması ve Drenaj Sorunları. ÇOMÜ Ziraat Fakültesi Dergisi, 24(2) $139-150$.

Dinç, U. \& Şenol, S. (1997). Toprak Etüd ve Haritalama. C..Ü. Ziraat Fakültesi, Ders Kitabı. No: 50, Adana.

Erdaş, O. \& Gümüș, S. (2000). Orman Yol Geçkilerinin Belirlenmesinde Coğrafi Bilgi Sistemlerinden Yararlanma Ümkanları üzerine Bir Araştırma. Turkish Journal of Agriculture and Forestry, 24, 611619, ТÜBITAK.

Everest, T., Sungur, A. \& Özcan. H. (2020). Gelibolu Namaztepe Bölgesindeki Farklı Fizyografyalar Üzerindeki Toprakların Bazı Fiziko-kimyasal Özellikleri ve Sınıflandırılması. ÇOMÜ LJAR, 1(1), 112.

Gıda Tarım ve Hayvancllık Bakanlığı. (2013). Toprak Tanımlama Kılavuzu. Uluslararası Sınıflandırma, İlişkilendirme ve İletişim İçin Bir Çerçeve. Guidelines for Soil Description (CCeviri). Tarım Reformu Genel Müdürlüğü FAO /IUSS /ISRIC.

Jackson, M.L. (1958). Soil Chemical Analysis. Prentice Hall Inc. Englewood Cliffs, N.J.

Rhoades, J.D. (1986). Cation Exchange Capacity. Chemical and Microbiological Properties. In: Methods of Soil Analysis, Part II. Pp: 149-157. ASA and SSSA Agronomy Monograph no 9(2nd ed), Madison.

Shovic, H., \& Mantagne C. (1985). Application of a statistical Soil-Landscape Model to an Order III Wildland Soil Survey. Soil Science Society of America Journal, 49, 961-968

Smith, G.D. (1983). Historical development of soil taxonomy-background. 23-49. In L. P. Wilding, N. E. Smeck, and G. F. Hall, eds., Pedogenesis and soil taxonomy. I. Conceptsand interactions, Amsterdam, Elsevier Science Publ.

Soil Survey Staff. (1993). Soil Survey Manual, USDA. Handbook No: 18 Washington D.C.

Soil Survey Staff. (1999). Soil Taxonomy. A Basic of Soil Classification for Making and Interpreting Soil Survey. U.S.D.A Handbook No: 436, Washington D.C.

Solmaz, M. İ. (2010). Eğimli arazilerin detaylı toprak etüd ve haritalanması için uzaktan algılama ve coğrafi bilgi sistemleri teknolojilerini kullanarak yeni yöntemlerin geliştirilmesi. Doktora Tezi, Çukurova Üniversitesi, Fen Bilimleri Enstitüsü, Toprak Anabilim Dall, Adana.

Şenol, N. D. (2017). Erzurum-Şenkaya-Gaziler yöresi toprak özelliklerinin yersel değişkenliğinin haritalanması. Yüksek Lisans Tezi, Atatürk Üniversitesi, Fen Bilimleri Enstitüsü, Toprak Bilimi ve Bitki Besleme Anabilim Dalı, Erzurum.

Şimşek, O. (2018). Alüvyal ovalarda farklı fizyografyalarda gelişen toprakların arazi kullanım planlaması ve coğrafi bilgi sistemleri ile haritalanması: aksu ovası örneği. Yüksek Lisans Tezi, Akdeniz Üniversitesi, Fen Bilimleri Enstitüsü, Toprak Bilimi ve Bitki Besleme Anabilim Dalı, Antalya.

Taşçı, E. (2015). Ardahan-Göle Platosunda çayır arazilerinde gelişen toprakların özelliklerinin belirlenmesi. Yüksek Lisans Tezi, Atatürk Üniversitesi, Fen Bilimleri Enstitüsü, Toprak Anabilim Dal, Erzurum.

Türkmen, F. (2011). Ordu ili topraklarının jeokimyasal özellikleri, genesisi ve sınıflandırılması. Ankara Üniversitesi Fen Bilimleri Enstitüsü, Toprak Bilimi ve Bitki Besleme Bölümü Anabilim Dalı, Doktora Tezi, Ankara.

U. S. Salinity Laboratory Staff. (1954). Diagnosis improvement of Saline and alkali soils. Agriculture Handbook No.60.U.S. Gevt. Printing Office. D.C.

Ünal, Ö. (2013). Konya ili, Seydişehir ilçesi, Gökhüyük, Gölyüzü ve Susuz Köyleri topraklarının detaylı toprak etütleri ve farklı yöntemlerle arazi değerlendirilmesi. Yüksek Lisans Tezi, Selçuk Üniversitesi, Fen Bilimleri Enstitüsü, Toprak Bilimi ve Bitki Besleme Anabilim Dalı, Konya. 